\title{
Kirker og godsejere i Vestslesvig i 1500-1600-tallet
}

af JESPER THOMASSEN

I kongeriget Danmark - både nord for Kongeåen og i de kongerigske enklaver i Vestslesvig - blev patronatsretten til kirkerne i ældre tid ofte overdraget til godsejerne. Men hvad betød denne ret egentlig for de fornemme herrer? Arkivar, ph.d. Jesper Thomassen, Aabenraa, belyser her spørgsmålet med henblik på kirkerne under de to store godser Schackenborg og Trøjborg.

\section{De kirkelige forhold i enklaverne}

I kongeriget nord for Slesvig overtog kongen ved reformationen den øverste kirkeledelse og dermed også jus patronatus til kirkerne, inklusive kaldsretten. ${ }^{1}$ Allerede før reformationen var enkelte jus patronatus blevet erhvervet af adelige, og de forblev i kraft, men for størstedelen af kirkerne forvaltede kongen patronatsretten, og han tildelte den, til hvem han ville. ${ }^{2}$ Dette førte til, at der allerede fra 1540 'erne blev givet patronatsrettigheder til en række adelige godser. ${ }^{3}$ Senere gik en del sammen med konge- og kirketienderne til de nye kirkelige institutioner, først og fremmest superintendenterne, latinskolerne og universitetet samt hospitalerne. ${ }^{4}$ I løbet af 1600-tallet tog afhændelserne til, og efterhånden fulgte tienderne med som en fast bestanddel af patronatsretten. I Christian den 5. og Frederik den 4.s tid begyndte et regulært salg, og efter 1720 var der stort set ikke en eneste kirke i kongeriget, der ikke havde en godsejer som patron. ${ }^{5}$ Sådan lå landet indtil begyndelsen af dette århundrede, hvor kirkerne blev selvejende med menighedsrådene som bestyrere.

I hertugdømmerne var udviklingen en ganske anden. Ved arvedelingen mellem Christian den 3. og hans yngre brødre i 1544 og igen i 1580/81 efter Hans den Ældres død blev Slesvig og Holsten som bekendt delt på kryds og tværs. Selvom de enkelte områder i Slesvig var mere sammenhængende end tilsvarende i Holsten, er indtrykket af området som et administrativt kludetæppe alligevel påfaldende. ${ }^{6}$ Kongen havde sin del, som blev administreret gennem Tyske Kancelli i København, de gottorpske hertuger og hertug Hans d. Ældre havde 


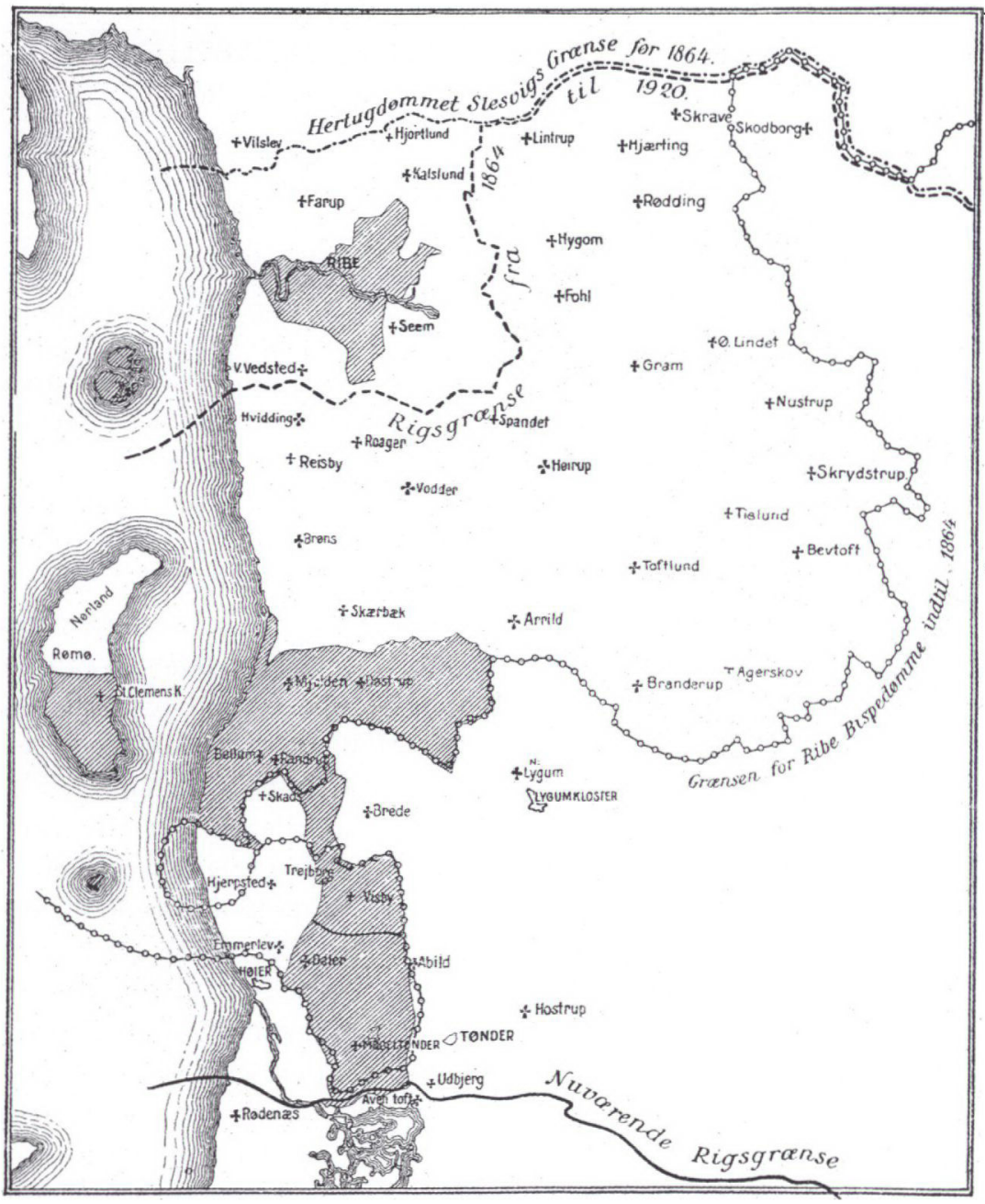

De kongerigske enklaver for 1864 (det skraverede). Foruden de på kortet afbildede områder omfattede enklaverne også den nordlige del af Sild (List), Vesterlandfor og Amrum. Gengivet efter Trap: De sonderjyske Landsdele, 1929.

deres dele. De adelige godser lå under fællesstyre. Både i de kongelige og hertugelige dele af Slesvig forblev patronatsretten hos landsherren. "Privatiseringen « af kirkerne må siges at have været en enestående dansk specialitet, og det kan derfor ikke undre, at de gottorpske hertuger og Hans d. Ældre ikke efterlignede denne. ${ }^{7}$ Anderledes 
mærkeligt er det, at patronatsretten til kirkerne i Slesvigs kongelige dele heller ikke blev afhændet. Umiddelbart nord for grænsen var antallet af private jus patronatus stort, men syd for beholdt kongen selv denne rettighed.

De kongerigske enklaver i Vestslesvig fulgte derimod mønstret fra kongeriget. Disse områder nordvest for Tender blev administreret gennem Danske Kancelli, og her blev overdragelsen af jus patronatus almindelig ligesom i kongeriget. Af kirkerne blev Visby, Randerup, Mjolden og Døstrup lagt under de mægtige Rantzauer på Trøjborg i 1579. ${ }^{8}$ Det vides ikke, hvilket omfang Rantzauernes kirkestyre oprindelig var tænkt at skulle have. I mageskiftebrevet fra 1579 hed det (her gengivet efter et tysk forlæg, som formodentlig har samme ordlyd, som den tekst Rantzau kendte): "... Deß gleichen haben wir auch gnädigst bewilliget Jhm undt Seinen Erben, daß jus patronatus, undt Vorsprach zu allen denen Kirchen in Løeharde, so der Kron zugehörich, mit Priester einzusetzen, so der Bischopen in Riepen examineret undt tuchtig erkendt sindt, doch der Bischopen visitation, und der Riepers Capitels freiheit, mit anhörung der Rechnung undt auch ander maßen hierdurch gäntzlich undt aller mäßen ungekränket ... «" ${ }^{9}$ Som udgangspunkt har Rantzau været af den opfattelse, at patronatsretten omfattede mere end blot kaldsretten. Ribe kapitel havde imidlertid i 1586 fået bekræftet sine rettigheder af Frederik den 2., herunder retten til at høre regnskaberne og til at bortfæste kirketienderne, kirkegårdene og kirkejorderne. ${ }^{10}$ Rantzau har vidst dette. En kopi af brevet var sendt til ham af Ribe kapitel allerede 1589. I 1590'erne blev patronatsretten indskrænket til kun at omfatte kaldsretten. Anledningen til denne begrænsning var Ribe kapitels ærkedegns klage over Peter Rantzaus ombygning af Visby kirke. Rantzau havde ladet de tre øvrige kirker betale en stor del af ombygningen, og ærkedegnen fandt derfor lejlighed til at hævde embedets gamle rettigheder over kirkerne. Rantzau blev i 1598 ved kongens retterting dømt til at tilbagebetale de øvrige kirker 2.200 daler og ærkedegnen 1.100 daler, og iøvrigt skulle han fremover lade kirkegodset være i fred. ${ }^{11}$ Hvad angår de øvrige enklavekirker Møgeltønder, Daler, Rømø, Amrum og Vesterlandfør, blev jus patronatus med kirkernes tiender samt jus patronatus med kirke- og kongetienden af Ballum og Emmerlev overdraget til Schackenborg efter 1661 . Hermed var rettighederne til alle kirkerne i enklaven overgået til adelige godsejere. ${ }^{12}$ Rømø, Vesterlandfør og Amrum gik imidlertid tilbage til kronen igen allerede $1683 .{ }^{13}$ 


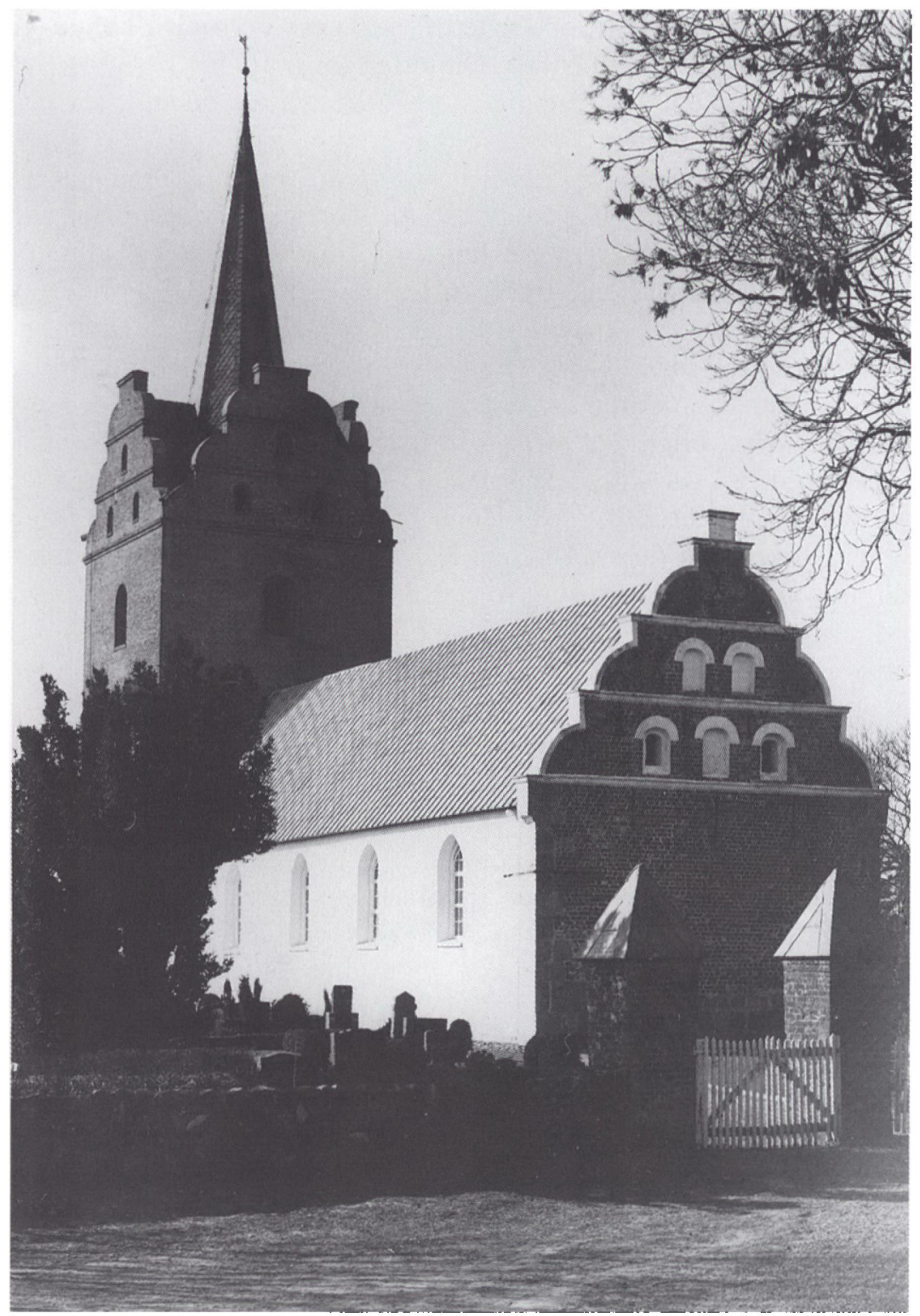

Visby kirke set fra syd-øst. Rantzaus ombygning omkring 1590 satte afgørende præg på kirken, der bl.a blev forsynet med svungne renæssance-gavle. Tårnet blev ved ombygningen forsynet med et højt og prangende spir med en dristig søjlekonstruktion og forgyldt blik pd taget. Spiret blev dog siden erstattet med et mindre og mere holdbart. Foto: Institut for Sonderjysk Lokalhistorie. 
I de sogne der grænsede op til enklaven, beholdt kongen (og hertugerne) patronatsretten. Sammenhængen mellem administrationen under Danske Kancelli og kronens afgivelse af patronatsretten var hårfin. Emmerlev sogn var delt imellem enklaven og hertugdømmet; men præstegården og kirken lå i enklaven, og derfor fik Hans Schack patronatsretten. I Hjerpsted, Skast, Højer og Brede var det omvendte tilfældet, og her beholdt landsherren patronatsretten til kirkerne. Disse sogne kom til at ligge som øer i det ellers godsejerdominerede område. ${ }^{14}$

Der findes næppe nogen entydig årsag til, at godsejerne i kongeriget skaffede sig jus patronatus til sognekirkerne. De ældste kendte patronatskirker stammer fra tiden før reformationen, og det er uvist hvordan og hvorfor disse æeldste patronatsrettigheder er blevet tilknyttet et gods. Det er dog kendetegnende, at de var forholdsvis få, og at gods og kirke lå i samme sogn. ${ }^{15}$ Efter reformationen fortsatte kongen som nævnt med at give patronatsrettigheder til udvalgte godsejere, og den tætte sammenhæng mellem sædegård og kirke var stadig markant. Af de efterreformatoriske overtagelser af jus patronatus stammer de fleste imidlertid fra tiden efter enevældens indførelse. Adskillige kirker blev påduttet kronens kreditorer som afbetaling af statens store gæld efter særlig Skånske Krig 1675-79, og ikke alle disse kirker lå nær ejerens gods. Men samtidig synes der også at have været en vis efterspørgsel fra godsejernes side - særlig efter de bedst beliggende kirker, d.v.s. dem der lå i umiddelbar nærhed af godset. Patronatskirkerne syd for Kongeåen hører alle til kategorien af jus patronatus, hvor der var en tæt sammenhæng mellem gods og kirke. Yderligere blev de også alle givet eller solgt til særlig udvalgte og højtstående personer.

Men hvilken interesse kunne en godsejer have $i$ at besidde patronatsrettigheder? Dette spørgsmål vil blive behandlet $i$ denne artikel på grundlag af de både m.h.t. erhvervelsestidspunkt og indhold vidt forskellige patronatsrettigheder, som ejerne af Schackenborg og Trøjborg havde. Der vil blive lagt særlig vægt på to mulige interesser, nemlig den økonomiske og den sociale/statusmæssige.

\section{Patronatsretten - den økonomiske betydning}

Umiddelbart skulle man tro, at de adelige godsejeres erhvervelse af jus patronatus til sognekirkerne var begrundet $i$ den økonomiske ge- 
vinst, der lå i overtagelsen af kirkernes administration. ${ }^{16}$ Dette synes imidlertid ikke (altid) at have været tilfældet. Lige siden reformationens gennemførelse i Christian den 3.s tid havde kongemagten stræbt efter at forbedre kirkernes og præsternes forhold. Ved hjælp af talrige indberetninger fra præsterne blev alle sognekirkernes og præsternes rettigheder registreret og denne viden samlet $\mathrm{i}$ kancelliet og hos provsterne $\mathrm{i}$ herredsbøgerne. ${ }^{17}$ De opnåede forbedringer var til gavn for religionsudøvelsen, og de skulle ikke sættes over styr ved kirkernes salg. Nok findes der mange eksempler på, at patroner eller adelige herremænd forgreb sig på kirkens ellers præsternes ejendom, men der findes ligeså mange eksempler på, at kongen greb ind og standsede overgrebene. ${ }^{18}$ Ved adskillige lejligheder både før og efter $1660 \mathrm{blev}$ det fastslået, at kirkernes ejendom skulle blive ved den enkelte kirke. En patron kunne altså ikke uden videre inddrage kirkens gods eller formue til eget brug.

I patronens ret til at disponere over kirkens indtægt lå en mulighed for at skabe en fortjeneste. Mod at vedligeholde kirken, afholde alle omkostninger til driften og alle uforudsete udgifter, måtte patronen oppebære kirkens overskud. ${ }^{19}$ Meget tyder imidlertid på, at der selv ved forholdsvis velhavende kirker var meget lidt at tjene i det lange løb. I kirkernes regnskabsbøger kan man følge de årlige udsving i overskuddene. Indtægten var som regel stabil, og ændredes kun lidt fra år til år. ${ }^{20}$ Udgifterne varierede derimod meget, og konstant blev der repareret på kirkerne. Perioder med overskud afløstes af perioder med underskud, og i det lange løb gik regnestykket stort set op. Det kunne derfor være en fordel for patronen stort set at lade kirken have sine indtægter $\mathbf{i}$ fred.

\section{Schackenborg}

For Schackenborgs kirkers vedkommende ser det ud til, at det netop var hvad patronerne, greverne Schack, gjorde. Det fremgår af skødet fra 1661, at grev Schack måtte betale 500 rd. for hver af de seks kirkers korn- og kvægtiende. For en enkelt af kirkerne, Ballum, fulgte kronens korn- og kvægtiende med til samme pris - d.v.s. i alt $3.500 \mathrm{rd}^{21}$ Umiddelbart er det svært at vurdere, om der var tale om en god forretning. I betragtning af at jus patronatus til Emmerlev kirke med kirkens og kongens tiende i 1673 blev sat til 1800 rd., kunne det tyde på, at det var det. ${ }^{22}$ Beregningen skruede ikke prisen kunstigt op; 
Emmerlev kirketiende var $\mathrm{i}$ jordebogen sat til $72 \mathrm{td}$. hartkorn, og ved handel med jus patronatus var normen, at en td. tiendekorn kostede $25 \mathrm{rd}$. Ballum kirkes kongetiende udgjorde $33 \mathrm{td}$. htk. og den kostede altså grev Schack 500 rd. i 1661, d.v.s. 325 rd. mindre end den normalt ville have kostet.

Grev Schack var imidlertid ikke tilfreds med en del af de indkøbte jus patronatus. Rømø, Vesterlandfør og Amrum kirker var formodentlig nærmere udgifts- end indtægtskilder. I en jordebog over grevskabet fra 1663 er der redegjort for kirkernes forhold. ${ }^{23}$ De tre kirker på øerne havde ifølge jordebogen ingen sikker tiendeindtægt, da øernes befolkning var fiskere og søfolk. Sognemændene gav efter formue lidt hvert år til kirkernes vedligeholdelse, og også kongen ydede et tilskud: "ellers de ikke af sognene haffuer kundet verit holdt ved lige". Skulle patronen leve op til sit ansvar for kirkens vedligeholdelse, ville det med tiden næsten uundgåeligt koste penge. Elendigheden gjaldt sikkert ikke kun kirkerne, hvilket har været årsagen til, at Schack i 1683 overlod kronen alt gods på øerne samt patronatsretten til kirkerne til gengæld for bl.a. retten til østersfiskeriet ved øerne og en årlig pension på $1000 \mathrm{rd}^{24}$

Greverne Schack var altså kommet forholdsvist billigt til patronatsrettighederne på fastlandet, og de urentable kirker på øerne var man sluppet af med i 1683. Som tidligere nævnt betød det imidlertid ikke, at der blev gjort fortjenester på de tilbageblevne kirker. Kirkernes regnskaber viser, at både tiender, kopenge, afgifter af kirkernes gods og rentepengene blev ved kirkerne - ihvertfald indtil $1705 .{ }^{25} \mathrm{I}$ de år hvor der var overskud, oppebar kirkeværgerne det, og beløbet blev ført til indtægt $\mathrm{i}$ det følgende års regnskab. Var der derimod underskud, måtte værgerne yde kirken kredit, og beløbet blev ført til udgift året efter. Ved det årlige regnskabs aflæggelse blev det giort op, hvor meget kirken skyldte værgerne eller omvendt - intet forsvandt i lommerne på nogen godsejer.

Denne situation ændredes dog, muligvis som følge af det økonomiske uføre grevskabet efterhånden kom ud i. I 1705 figurerer der en udgiftspost på 95 rd. 5 skilling i kirkeregnskabet for Møgeltønder kirke med forklaringen: "Till Skole Huusets Opbygning “. En udgift som kirken strengt taget ikke skulle have afholdt. 1714 skete der til gengæld noget, som utvetydigt pegede i retning af en hårdere udnyttelse af kirkens indtægter. Møgeltønder kirke havde i årene 1703 til 1714 oparbejdet et overskud på ikke mindre end 550 rd. 41 skilling, og 
dette beløb blev ved regnskabets afslutning på grevens befaling overfort som indtægt $\mathrm{i}$ godsregnskabet. Året efter måtte kirken begynde på bar bund, men den oparbejdede dog snart en formue igen. I 1720 var formuen på $430 \mathrm{rd}$. 28 skilling. I løbet af 1720'erne og 30'erne blev det stadig mere almindeligt, at kirkens overskud blev brugt på godset. Det foregik oftest ved, at kornindtægterne (tienden) blev leveret direkte til Schackenborgs ladefoged. Fra og med dette tidspunkt blev kirkerne en regulær indtægtskilde for patronen.

En enkelt af Schackenborgs patronatskirker udgjorde en undtagelse fra reglen om, at godset indtil begyndelsen af 1700-tallet ingen indtægt havde af kirkerne, nemlig Emmerlev. Dog var det ikke kirken, men præsten der måtte holde for. De særlige forhold stammede tilbage fra før reformationen, og må siges at have været helt ekstraordinære. På et tidspunkt havde ejeren af den adelige sædegård Kogsbøl givet fem gårde i Emmerlev sogn til Vor Frue alter i Ribe. Da altergodset efter reformationen blev givet tilbage til donatorerne eller deres arvinger, krævede Ifver Eriksen til Kogsbøl i 1547 gårdene tilbageleveret. ${ }^{26} \mathrm{Da}$ altergodset imidlertid blev anvendt til underholdning af en kapellan ved Ribe kapitel, enedes man om, at landgilden i fremtiden skulle gives til kapellanen, mens herrerne på Kogsbøl beholdt de øvrige rettigheder.

I 1690 skulle landets præster indberette om kaldenes beskaffenhed. Præsten i Emmerlev Claus Clausen forfattede i den anledning en udførlig beskrivelse. ${ }^{27}$ Heri skrev han blandt andet, at kapellaniet de sidste 80 år ikke havde været besat, og at præsten selv forrettede hele tjenesten. ${ }^{28}$ Af de fem altergårde var fire tilbage, og præsten modtog for sin tieneste landgilden samt udbyttet af "Capellan-Moose (tidligere kaldet "Vor Frue Moose «); en ordning der formodentlig havde eksisteret de nævnte 80 år, og som indebar, at præsten som erstatning for Ribe kapitlets manglende indtægt måtte yde en stor del af sin korntiende til ærkedegnen i Ribe. Ved grev Schacks overtagelse af jus patronatus til Emmerlev kirke fulgte denne særlige indtægt med. Schackenborg modtog derfor årligt 22 Riper ørtug byg af præstens korntiende.

Selvom Schackenborgs jus patronatus for 1600-tallets vedkommende ikke indeholdt nogen direkte økonomiske fordele ud over indtægten fra Emmerlev præstetiende, så var der jo også kongetienderne. I Slesvig fandtes normalt ingen kongetiende, og tienden blev derfor kun delt mellem kirke og præst, men i flere af enklavesognene blev 


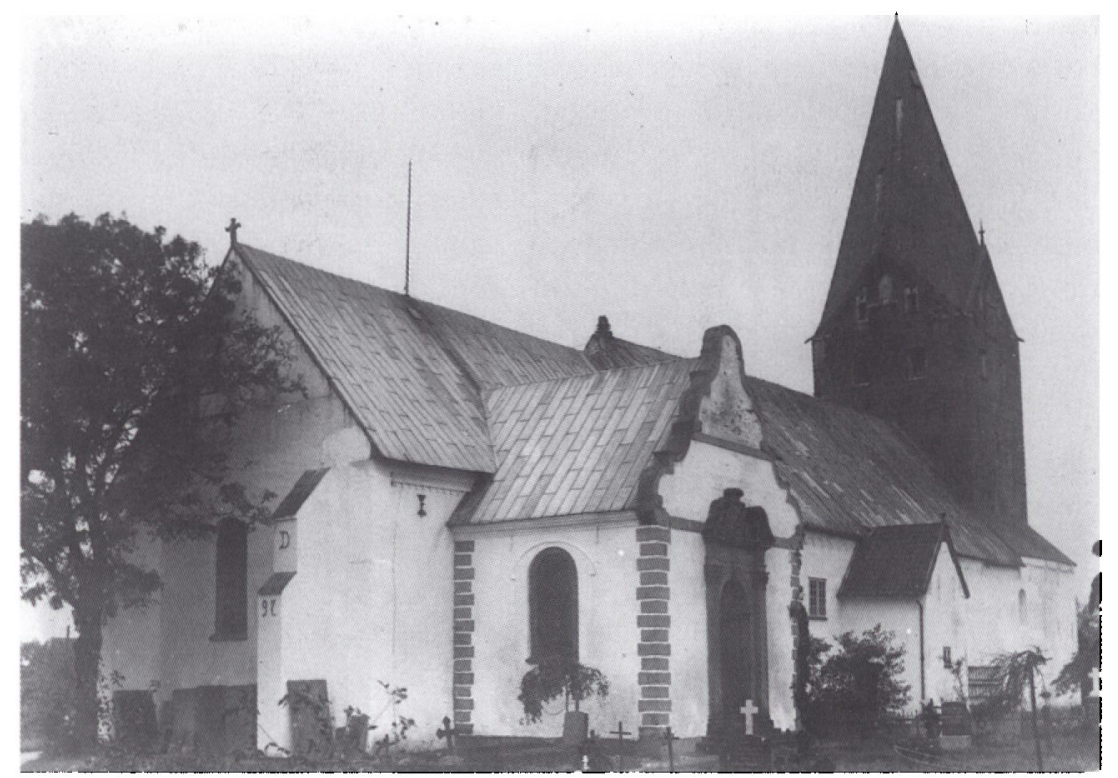

Mogeltender kirke set fra nord-vest. Begge tilbygninger var reserveret grevefamilien. Forrest ses det Schackske kapel og bag dette den murede opgang til det grevelige pulpitur. Foto: Institut for Sønderjysk Lokalhistorie.

der givet kongetiende som i kongeriget. Som tilfældet var nord for Kongeåen, opkrævedes kongetienderne direkte af bønderne, og de var reelt uden forbindelse til kirkernes og præsternes indtægter. Disse tiender kunne nok spille en rolle for godset. I 1671 blev Hans Schack ophøjet i den nystiftede grevestand, men hans gods Møgeltønderhus bestod på daværende tidspunkt kun af ca. $1.660 \mathrm{td}$. hartkorn. Da der ifølge grevernes privilegier krævedes $2.500 \mathrm{td}$. hartkorn til et grevskab, manglede Schack altså ca. 840 td. - helst i nogenlunde nærhed af Møgeltønderhus. ${ }^{29}$ Den nærmeste mulighed var det gejstlige gods i Ribe, som kongen jo rådede over. For en fordring på 30.000 rd. fik han udlagt ca. $432 \mathrm{td}$. hartkorn af Ribe domkapitels og hospitals gods i Højer, Lø og Hvidding herreder. Desuden fik han jus patronatus med kongetienden til Emmerlev sogn, hvilket udgjorde 72 td. hartkorn. Hans Schack døde i 1676, inden grevskabet var blevet oprettet. Det blev derfor sønnen Otto Didrik Schack, der fik godset erigeret til grevskab - med dispensation for de manglende $300 \mathrm{td}$. hartkorn.

Det kan ikke afgøres, hvor stor en andel af grevskabets hartkorn der stammede fra patronatskirkerne - men det må have været en ikke 
helt uvæsentlig del. Alene Emmerlev kongetiende udgjorde $72 \mathrm{td}$. hartkorn. Ballum kongetiende blev oprindelig sat til $72 \mathrm{td}$., men i jordebøgerne blev den imidlertid nedskrevet til $33 \mathrm{td} .{ }^{30}$ I Møgeltønder og Daler blev der ikke givet kongetiende, da tienden kun deltes mellem kirke og præst. Møgeltønders, Dalers og Ballums kirketiender blev ikke opgjort $\mathrm{i}$ hartkorn $\mathrm{i}$ jordebøgerne. Tilsammen blev der i de tre sogne ydet ca. 124 ørte tiendekorn, hvilket var to og en halv gange så meget, som der blev ydet i kongetiende i Ballum. Med lidt forsigtighed kan de tre kirkers samlede tiendehartkorn derfor anslåes at have udgjort ca. 70 td. Hertil kom yderligere kirkernes fæstere, der dog fortrinsvis havde små ejendomme. Selvom kirkerne ikke bidrog væsentligt til godsets økonomi, var de alligevel uundværlige for det hartkorns-fattige grevskab.

\section{Trøjborg}

Efter dette overblik over kirkerne under Schackenborg vil vi se på det andet store enklavegods, Trøjborg. Her undgik de fire kirker ikke helt patronens overgreb, selvom det næppe skete udelukkende med tanke på den økonomiske gevinst. Som før nævnt foretog Peter Rantzau ved hjælp af de tre øvrige kirkers indtægter en ombygning af Visby kirke ca. 1590 , for hvilket han ved kongens retterting blev dømt til at betale erstatning samt for fremtiden holde sig fra kirkernes gods. Rantzau fik indskærpet, at kun kaldsretten og ikke patronatsretten tilhørte ham. Af ærkedegnens klager over Rantzau og de øvrige akter i sagen fremgår det, at han ikke blot havde benyttet de tre kirkers indtægter til ombygningen af Visby kirke. ${ }^{31}$ Også kirkens jordegods havde han forgrebet sig på: En kirkeeng og et kirken tilhørende hus i Mjolden havde han lagt under Trøjborg, mens en kirkeeng i Randerup var givet til præsten sammesteds, Hr. Iver. Begge enge og huset var allerede fæstet bort af ærkedegnen, men det så Rantzau stort på. Dog skal det siges, at kirkeengen i Randerup ikke var kommet til præsten med Rantzaus gode vilje. Tværtimod havde præsten Iver Mortensen i 1583 krævet jord af Rantzau med henvisning til lov og ret, og sagen blev sandsynligvis afgjort ved herredstinget. ${ }^{32}$

Peter Rantzaus mulige sociale gevinster ved besiddelsen af Visby kirke 1590 vil blive behandlet i et senere afsnit. Her skal blot konstateres, at de fire patronatskirker sandsynligvis ikke gav noget økonomisk overskud til Trøjborgs ejere i den efterfølgende tid. Der findes 

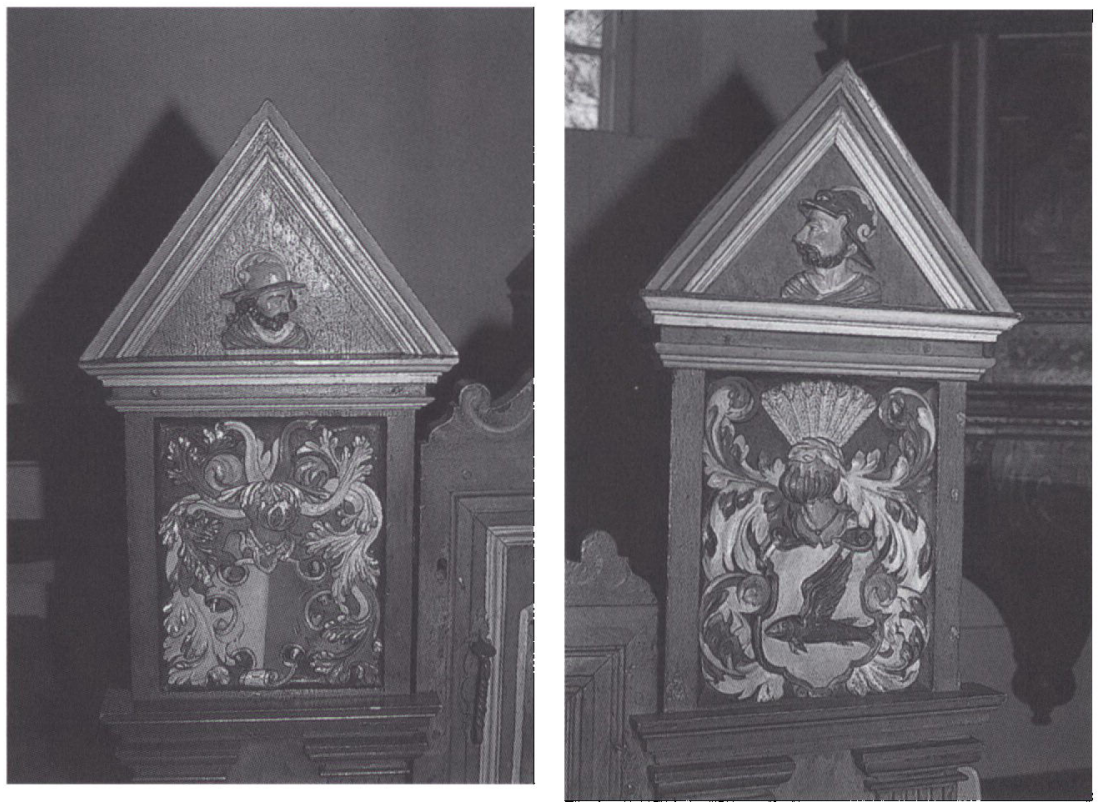

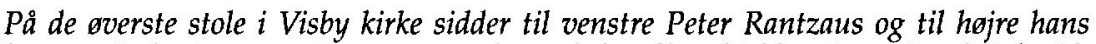
hustru Catharina von Dammes smukt malede vaibenskjolde. Foto: Knud Schmidt Nielsen.

ingen optegnelser derom i godsarkivets regnskaber og jordebøger fra 1600-tallet. Tilsvarende viser kirkeregnskaberne i samme periode, at alle indtægter årligt blev opkrævet til kirkerne selv. ${ }^{33}$ Ærkedegnen i Ribe levede op til sit ansvar som patron for kirkerne, og efter episoden i 1590'erne har Trøjborgs ejere næppe haft indflydelse på økonomien. Skønt rent hypotetisk er det spørgsmålet, om Trøjborgs ejere havde kunnet opretholde den agressive linje overfor kirkerne - også selvom ærkedegnen og kapitlet i Ribe ikke havde klaget til kongen. Det må have ramt de tre kirker hårdt at få reduceret indtægterne i flere på hinanden følgende år. Selv med tilbageførslen af godt og vel 700 daler til hver af kirkerne klarede de sig ikke overvældende godt i tiden der fulgte. Formodentlig er størstedelen af pengene blevet brugt til anskaffelse af den efter reformationen obligatoriske prædikestol; dette inventar blev ihvertfald indkøbt til både Mjolden, Randerup og Døstrup kirker omkring århundredeskiftet. ${ }^{34}$

Ejerne af Trøjborg mistede imidlertid ikke interessen for kirkernes økonomi, hvilket fremgår af en række overvejelser som godsets da- 
værende ejer Otto Friedrich Buchwald i 1738 eller 1739 gjorde sig vedrørende kirkerne. Buchwalds tanker kendes fra en vejledning, som han skrev til sønnen Friedrich Buchwald umiddelbart før sin død i december 1739. ${ }^{35}$ Vejledningen omhandler alle sider af godsets drift med formaninger om, hvad Friedrich særlig skulle være opmærksom på. O. F. Buchwalds gengivelse af striden mellem bispen i Ribe og Peter Rantzau viser, at de fire patronatskirkers tiender efter hans opfattelse retteligt burde tilhøre Trøjborg: "... wie in Dennemarck gebrowlich «. Men de var kommet fra godset da: "... einer von meinen vorfahren etwas getahn, darüber ihm diese zehend genommem und dem Bischoff von Ripen zugeleget worden ...«. Altså ikke noget om, at tienderne sammen med kirkernes øvrige indtægter faktisk aldrig havde været indeholdt i Peter Rantzaus patronatsret. O. F. Buchwald forestillede sig den situation, at tienderne igen skulle kunne komme til Trøjborg på bekvemmelig vis. I så fald skulle sønnen overveje sagen nøje, idet tienderne udgjorde en del af bispens løn (så han skulle jo have erstatning for dem). Buchwald var også opmærksom på en væsentlig fordel ved ikke at besidde kirketienderne; nemlig fritagelsen for vedligeholdelsespligten. Sønnen skulle blot holde øje med, at bispen også i fremtiden vedligeholdt kirkerne.

En ting var imidlertid kirkerne, en anden præsterne og deres gårde. I O. F. Buchwaldts vejledning findes vidnesbyrd om, at Trøjborgs ejere havde tilgodeset præsterne ved patronatskirkerne. Han nævner de naturalieindtægter, som var tillagt præsterne, men gør samtidig sønnen opmærksom på, at hans moder Anna Dorothea Rantzau havde forsøgt at tage dem fra præsten i Visby. Ydelserne var derfor næppe at anse for en pligt, der påhvilede godset. Interessen for præsterne kan spores helt tilbage til Peter Rantzaus tid. I 1591 indgik han en skriftlig aftale med den nylig kaldede præst i Visby Andreas Jacobsen (Andreas Jacobi). Præsten skulle herefter årligt modtage 60 mark lybsk og to ørte rug, byg og havre af Trøjborg. Herforuden skulle han have vinter- og sommersæd (6 ørte, 4 skp. rug, 4 ørte byg og 4 ørte havre), hvilket skulle sås af godset i præstens livstid. Sidst, men ikke mindst, fik han et velbygget hus og en "wische« (våd eng) beliggende i Mollerup skov; af engen skulle degnen dog bruge en femtedel. Til gengæld for dette skulle præsten love ikke at tage et andet kald uden Rantzaus tilladelse, og at han eller hans arvinger skulle vedligeholde huset. Forbedrede han eller arvingerne huset, skulle de have erstatning. ${ }^{36}$ Aftalen blev indgået på et tidspunkt, hvor Rantzau stadig var 
overbevist om sin ret til kirken. Det kan være som følge heraf, at han følte sig forpligtet til at hjælpe præsten.

Det vides ikke, hvilke naturalieindtægter Trøjborgs ejere skulle have givet til præsterne $i$ de tre andre enklavesogne under godset, Mjolden, Døstrup og Randerup. Kilderne er få for 1500- og 1600-tallets vedkommende og senere synes indtægternes forbindelse til Trøjborg at være glemt, eller de var forsvundet. I Christian 4.'s reces fra 1643 blev det påbudt at føre bøger over kirkernes og præsternes indtægter og øvrige forhold. ${ }^{37}$ Fra 1649 er bevaret en herredsbog for Lø herred, der består af præsternes egenhændige indberetninger. ${ }^{38}$ Indberetningerne fra de tre ovennævnte sogne vidner om præsternes svære vilkår, men der er ingen oplysninger om, at Rantzauerne skulle have hjulpet dem. Særlig i Randerup og Mjolden stod det slet til. Antallet af tiendeydende gårde var henholdsvis 12 og 18, og ofte blev høsten ødelagt af blæst og saltvand. De få mennesker i sognet kunne heller ikke yde noget særligt i kvægtiende, offer og smørbyrd, og præstegårdenes avl var forholdsvis ringe. Bedre stod det til i Døstrup, hvor antallet af gårde var højere (40), vejret mere nådigt og præstegårdens avl større. Men heller ikke her nævnes Trøjborgs ejere. I indberetningen fra Visby kunne præsten derimod fortælle, at salig Peter Rantzau havde benådet præstegården med et areal i Mollerup enge, der gav 20 læs hø. Muligvis er der tale om den "Wische“, som er omtalt ovenfor.

Brede sogn lå ikke i Ribe stift. Det hørte derimod under Slesvig stift, og derfor findes der ingen tilsvarende indberetning herfra. Alligevel er der vidnesbyrd om, at præsten er blevet tilgodeset af søstrene Anna Dorothea Buchwald og Margareta Hedewig von Ahlefeldt til Trøjborg. I 1686 stadfæestede de overdragelsen af brugsretten til 13 blokke land på Brede mark til pastoratet i Brede: "... zu Gottes Ehre, und des priesterthumbs besten ... «. ${ }^{39}$ Den fungerende præst Andreas Fabricius måtte have arealerne uden afgift, men hans efterfølgere skulle betale 2 mark lybsk. O. F. Buchwald nævner de 13 »kleine blöcke« land i sin vejledning, og han må have haft dem i frisk erindring. Den 3. september 1738 - omtrent samtidig med at han skrev sin bog til sønnen - blev brevet fra 1686 læst på landstinget i Viborg. Måske har han forsøgt at få dem tilbage eller forhøje afgiften? Under alle omstændigheder er der noget der tyder på, at de skiftende godsejere fortrinsvis har haft interesse for de nærmest liggende sogne Visby og Brede - uanset at de tre øvrige sognepræster nok kunne have haft hjælp behov. 


\section{Patronatsretten - den sociale betydning}

Når der ikke var nogen væsentlig økonomisk gevinst ved patronatsretten, er det nærliggende istedet at søge godsejernes interesse for kirkeejet $\mathrm{i}$ den indflydelse det havde på deres sociale position. Der kan næppe herske tvivl om, at enkeltpersoner siden middelalderen har benyttet kirkerne som et af de steder, hvor de kunne vise deres position og betydning. Fra højmiddelalderen er der kun overleveret spredte vidnesbyrd om denne brug af kirkerne, og ikke alle vidnesbyrdene er entydige og klare. Mange har ment, at de romanske stenkirker - og før dem trækirkerne - var enkelte stormænds værk..$^{40}$ Forholdt det sig sådan, kan byggerierne meget vel have haft baggrund i en hævdelse af social position - foruden selvfølgelig personlig fromhed. Det kan imidlertid ikke udelukkes, at i det mindste nogle kirker har været kollektive projekter, udført på basis af det der efterfølgende skulle blive til et sognefællesskab. I så fald har individets rolle næppe haft den store betydning. I løbet af senmiddelalderen udviklede der sig under alle omstændigheder plads til individets hævdelse i kirkerne. For den der gerne ville sætte sig et mindesmærke, ovenikøbet til gavn for frelsen, kunne der indstiftes tidebønner og altre, der kunne gives inventar og gaver $\mathrm{i}$ form af rettigheder, jordegods og meget mere.

Reformationen medførte $\mathrm{i}$ første omgang en nedtrapning af folks brug af kirkerne som steder, hvor de kunne manifestere sig selv og deres status. ${ }^{41}$ De mange katolske former for hævdelse af gudsfrygten ved gavegivning forsvandt. I kirkerne kom der fokus på prædikestolen og døbefonten, mens interessen for den øvrige udsmykning aftog. Først omkring 1570 'erne synes lysten til at investere $\mathrm{i}$ inventar og udsmykning igen at være kommet tilbage. Der opstod nye måder at synliggøre sig på i kirken i form af epitafier, herskabsstole og fremtrædende gravmonumenter. Dette var også tilfældet i Vestslesvig, hvad Tønder kirke så tydeligt viser. Adelen havde sin storhedstid, borgerstanden voksede sig stærk og enevældens indførelse 1660 syntes at have stimuleret behovet for manifestion og selviscenesættelse.

\section{Trøjborg}

Visby, Mjolden, Randerup, Døstrup og Brede sogne udgjorde kernen i Trøjborgs godskompleks i hele 15- og 1600-tallet. Skulle Rantzau for 
alvor markere sin indflydelse i området, var disse kirker højst aktuelle. Som tidligere nævnt lå kun en del af Brede sogn i den kongerigske enklave; præstegården og kirken lå i hertugdømmet. Hertug Hans d. Ældre havde patronatsretten, hvilket blev stadfæstet 1576-78. ${ }^{42}$ Det var derfor naturligt, at Peter Rantzau ikke fik jus patronatus til Brede kirke i 1579. Dette kan godt tænkes at have ærgret Trøjborgs ejere. Dels var Brede det sogn, hvor Trøjborg havde flest fæstere, og hvor flest gårde blev erhvervet $\mathrm{i}$ perioden. ${ }^{43}$ Ved overtagelsen af Trøjborg i 1579 boede knap 30 af godsets fæstere i Brede sogn, men allerede i 1589 var antallet vokset til ca. 70 - dog var de fleste nytilkomne (ca. 30) kun kådnere. I 1679 var antallet af gårde i sognet øget til 53, og kådnernes antal tilsvarende reduceret til fire. Formodentlig var dette resultatet af sammenlægninger. Derudover lå Brede sogn godt $\mathrm{i}$ forhold til hovedgården - nærmere end Døstrup, Randerup og Mjolden.

Tilbage var altså de fire patronatskirker, og ligesom senere tiders kirkeejere koncentrerede Rantzau indsatsen om Trøjborgs egen sognekirke, Visby. Peter Rantzaus byggeri på Visby kirke i 1590'erne kan meget vel have været et udtryk for ønsket om at benytte kirken til selvhævdelse. I lyset af ærkedegnens klage og kongens efterfølgende dom over Rantzau forekommer hans ombygning af Visby kirke og udnyttelsen af de øvrige tre kirker som et voldsomt overgreb. Men Rantzau har formodentlig følt sig i sin gode ret til at handle som han gjorde. Kongen havde givet ham betydelige rettigheder i Lo herred, og under normale omstændigheder omfattede jus patronatus mere end blot kaldsretten.

Rantzau havde foretaget byggearbejder siden overtagelsen af Trøjborg slot i 1579, og i slutningen af 1580'erne må hans prægtige nye renæssanceslot have stået færdig. Visby kirke blev ikke genopført fra grunden, men ved til- og ombygninger blev den gamle kirke skjult. Herved kom slot og kirke til at indgå $i$ en arkitektonisk enhed - uden dog at være hinanden helt lig - og beskueren kunne ikke være i tvivl om den fælles bygherre. Foruden de tidstypiske svungne gavle blev kirken forsynet med et mægtigt tårn, der foroven afsluttedes af et spir. Som tagbeklædning blev anvendt fortinnet blik, som med ærkedegnen i Ribe Ægidius Lauritsøns ord: »... skinnede oc pralede megit i marcken ...«. ${ }^{44}$ Ærkedegnens udtalelse viser, at Rantzau opnåede hvad han ville ved at bygge stort og flot - nemlig at folk blev opmærksomme på hans magt. Den forargede ærkedegn var mest tilfreds med, at blikket snart blæste af kirken og måtte erstattes med træspån 
og bly; til stor udgift for kirken. Alene den omstændighed at Rantzau på det nærmeste byggede en ny kirke, er bemærkelsesværdig. Både i Slesvig og i Danmark blev der kun bygget meget få nye kirker efter reformationen, i Nordslesvig foruden Visby kirke kun Kegnæs. Karakteristisk nok var det de mægtigste og mest magtfulde godsbesiddere der gav sig af med den slags, som f.eks. kansleren Johan Friis i Hesselager på Fyn og senere Ellen Marsvin på Thurø og Podebuskerne på Kørup og Einseidelborg.

Kirken kom til at indgå i Rantzaus visuelle magtdemonstration. Også kirkens indre forandredes i takt hermed. Den væsentligste del af inventaret blev fornyet ved samme lejlighed, bl.a. prædikestolen, døbefonten, altertavlen og stolestaderne (evt. gavlene). Rantzaus våben sås flere steder, f.eks. på altertavlen og døbefonten. Siddepladserne $i$ kirken var en nyskabelse, der formodentlig først for alvor trængte frem i løbet af 1500-tallets første halvdel. For en godsejer var stolestaderne oplagte, når der skulle gøres opmærksom på vedkommendes centrale position i sognet. Der kan have været stader i kirken før 1590, men Rantzau fornyede dem. De forreste stole forsynede han med gavle med sit våben. Den mest fremtrædende plads var hans og det kunne alle se, også selvom han oftest var fraværende fra Trøjborg, og derfor ikke deltog i gudstjenesterne.

Peter Rantzau har med god grund kunnet anse hele kerneområdet i godsbesiddelsen, Lø herred, som sit domæne. Her var han herre: Bønderne var hans fæstere, herredsfogeden udnævnte han selv, og alle kongelige rettigheder tilkom ham. Kaldsretten til de fire patronatskirker indgik fint i denne sammenhæng. Den sidste manifestation $\mathbf{i}$ form af et gravmæle i kirken kunne det imidlertid ikke blive til. Trøjborg var blot et af Peter Rantzaus mange godser, og næppe det han følte sig mest knyttet til. Han døde i 1602 på Ahrensburg i Holsten, på slottet som han selv havde ladet opføre i 1590'erne sammen med en kirke, i hvilken han blev begravet. ${ }^{45}$

\section{Schackenborg}

Schackenborgs sognekirke var Møgeltønder, og her blev der ikke tale om nogen storstilet ombygning. Alligevel satte patronerne efterhånden deres præg på kirken, først og fremmest ved at tilegne sig den fornemste og mest centrale placering i kirkerummet. I 1691-92 blev to pulpiturer opsat, og et allerede eksisterende fik fornyet udsmyknin- 
gen, så det passede til de to nye. Det fornemste af pulpiturerne (med udvendig muret trappehus) lige overfor prædikestolen var grevskabets. ${ }^{46}$ Her kunne herskabet trone højt hævet over det meste af menigheden, sådan som herremænd gjorde det mange andre steder i riget på samme tid.

Det vides ikke med sikkerhed, hvor Schackenborgs ejere havde deres pladser i kirken for 1692. Sandsynligvis var det på de forreste bænke $i$ begge sider af kirkens skib (kvinder mod nord, mænd mod syd). Det fremgår af et udførligt stolestaderegister fra 1692, at disse stole tilhørte Schackenborg. ${ }^{47}$ I registeret er noteret, at overinspektøren og de grevelige betjente sad øverst, dernæst fulgte godsets folk, og endelig var der en ledig plads, som blev bevilget kirken at leje ud. Den ledige plads var formodentlig opstået ved, at herskabet rykkede op på det nye grevelige pulpitur, og godsets folk rykkede frem på de ledige pladser.

Folks placering $\mathrm{i}$ kirken afspejlede deres position i sognet og deres økonomiske formåen. Stolestaderegisteret fra 1692 illusterer den rolle kirken havde ved opretholdelsen af det sociale hierarki i sognet - et hierarki hvor Schackernes befandt sig helt oppe i toppen. Registeret blev ifølge indledningen lavet på foranledning af Sophia Dorothea Marschalk, grevinde af Schack, og sandsynligvis havde hun afgørende indflydelse på dets udformning. Hun underskrev det, og forsynede det med en personlig efterskrift. Heri tillod hun sin søn at forandre indholdet, når han om fire år blev myndig. Registeret nævner først skibets sydlige side, mandssiden. På de forreste bænke sad som nævnt først overinspektøren, derefter betjentene og i tredje stolerække godsets øvrige folk samt fem sognemænd, der havde råd til at betale en leje på tilsammen $1 \mathrm{mk}$. og 16 skilling. Pladserne var skibets bedste (og kirkens dyreste), idet de var placeret umiddelbart foran prædikestolen. Efter de tre første stolerækker fulgte 15 rækker med bolsmænd, der samlet betalte en afgift i naturalier og penge til degnen og organisten. Bolsmændene havde ikke faste pladser, men der skulle "... over alt her udi kircken holdis den skick efter gammel sædvane, og kong: Mayt:s lougs tilhold, at de unge skall ydmyge sig for de gamle og søge deris sted og sæde udi stolene der efter ...«. Efter bolsmændene fulgte tre stolerækker til mænd, der hver betalte seks eller otte skilling.

I skibets nordre side sad først godsinspektørens kone og de øvrige kvindfolk fra godset. Yderligere havde grevinden bevilget, at præ- 


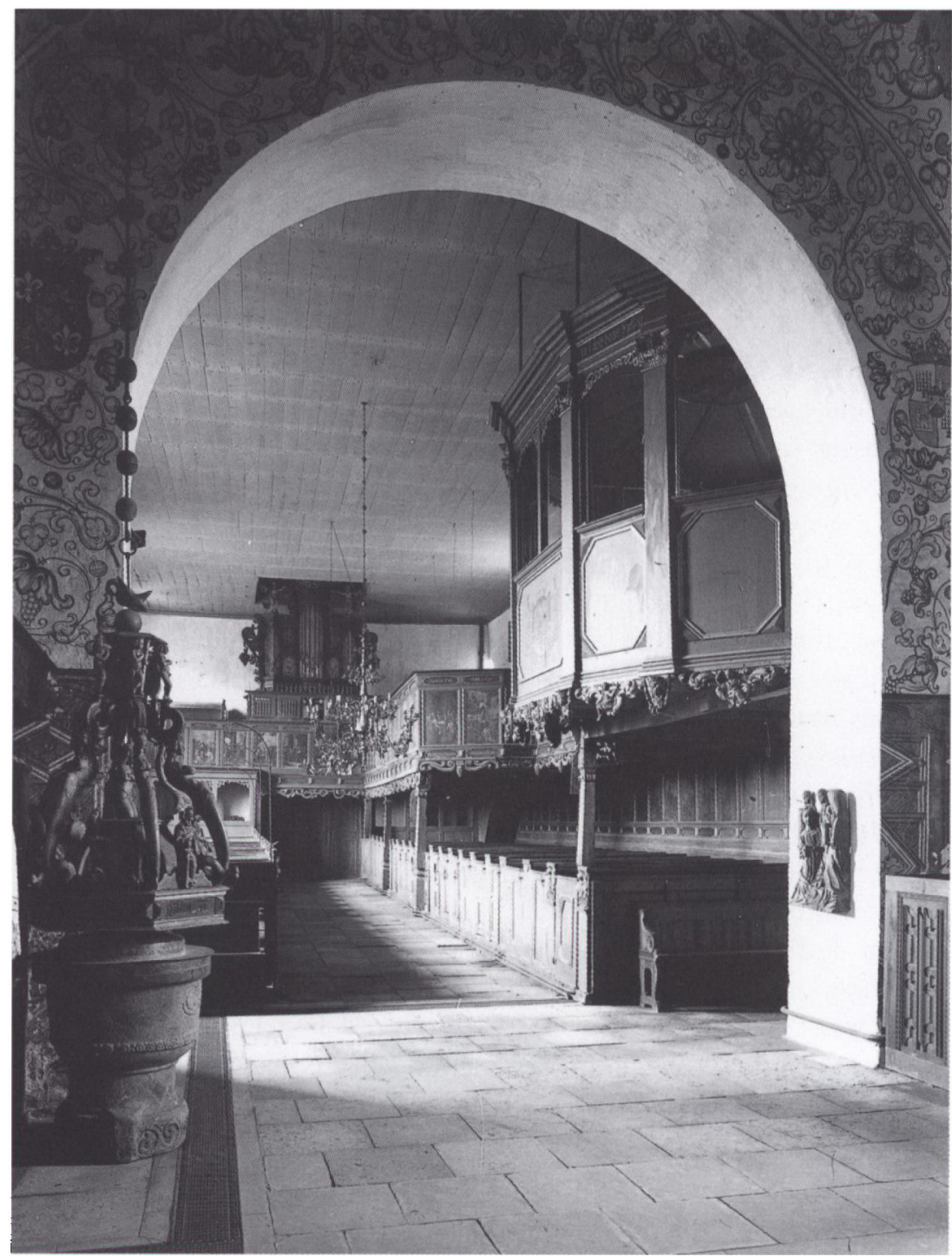

Møgeltonder kirke set fra koret. Forrest po̊ nordvæggen ses det grevelige pulpitur. Prædikestolen var placeret direkte overfor (her skjult af korbuen). Umiddelbart bag det grevelige pulpitur (på samme væg som dette) ses det nye pulpitur. På endevæggen sad det gamle pulpitur, hoorpå ogsd orgelet var anbragt. Det var bygget for Schackenborgs oprettelse, og pladserne her var billige. På det nye pulpitur tronede efter 1692 sognets ledende mænd med greveparret $i$ spidsen. Kvinderne og bolsfolkene mätte nøjes med pladserne på kirkens gulv. Foto: Nationalmuseet. 
stens samt birke- og delefogedens koner fik plads her. En enkelt gårdmandskone lejede sig ind formedelst 16 skilling. Derefter fulgte 15 stolerækker til bolsmændenes koner, og endelig blev de sidste fem rækker lejet ud til kvinder for henholdsvis tre og fire skilling. Efter skibet kom turen til korets sydlige side, helt oppe ved alteret, hvor tre stole var besat af kvinder, der hver svarede otte skilling. I den øvrige del af koret var der også kvinder; på de nordlige stole gav hver tre skilling og på den sydlige to og en halv: "Jn Consideration, das diese die geringste stühle sein ...«. Fra disse pladser kunne præstens prædiken dårlig høres, og prædikestolen end ikke ses. I koret var døbefonten placeret, og to rækker var derfor reserveret til faddere og kirkegangskoner. På kirkens dårligste pladser var således pøblen og kvinderne placeret. Kun de per tradition fornemste stole ved prædikestolen var besat med folk med høj status, og disse har formodentlig lyst op i forsamlingen på gulvet.

Det nye pulpitur var anbragt på kirkens nordvæg, og her var forholdene anderledes end $\mathrm{i}$ kirkens bund. Her sad gårdmændene sammen med sognets øvrige »middelklasse« formedelst otte og en halv skilling per person. ${ }^{48}$ Det grevelige pulpitur var også placeret på nordvæggen i umiddelbar forlængelse af det nye pulpitur; direkte overfor prædikestolen. I skibet var der foruden de to nye pulpiturer også et gammelt på vestvæggen (endevæggen). Det bestod af en nord- og en sydside; adskilt af det i 1679 installerede orgel. Også her sad der mænd, men prisen var kun fire skilling på sydsiden (den bedst placerede $\mathrm{i}$ forhold til prædikestolen) og to skilling på nordsiden. Pulpituret var bygget på kirkens bekostning før Schackenborgs oprettelse, hvilket grevinden tog hensyn til ved prisfastsættelsen. Højt over pøbel og kvinder sad således sognets vigtigste personer, i pulpiturer der dog synede af lidt i forhold til det grevelige. Ingen som var til stede i kirken kunne være i tvivl om, hvordan forholdene i sognet var - her var greveparret konge og dronning.

Modsat Trøjborgs ejere blev Schackerne begravet i deres kirke, i krypten under koret. Oprindelig havde stedet fungeret som begravelse for Rantzauerne, der umiddelbart før reformationen og igen 1564-99 havde haft Møgeltønderhus i forlening. 1696 blev deres lig imidlertid flyttet for at gøre plads for den grevelige familie fra Schackenborg, der dermed overtog den fornemste begravelsesplads. I længden var dette ikke tilstrækkeligt, og 1763 blev et anseeligt gravkapel i tilknytning til koret bygget; ligene i krypten fik dog lov at blive, hvor de var. 


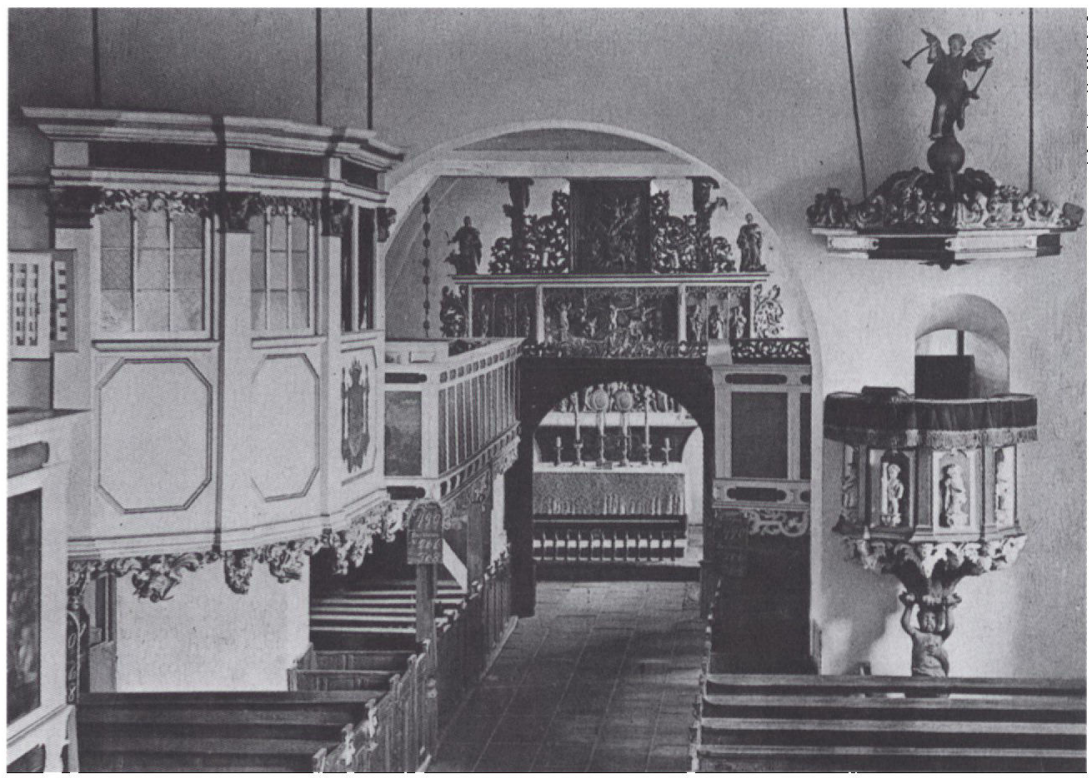

Møgeltønder kirke set fra orglet mod koret. De to pulpiturer $i$ koret blev forst sat op $i$ 1737, og de eksisterede altsả ikke $i$ 1692, da stolestaderegisteret blev lavet. Udvendig på kirken var et muret trappehus, hvorfra man havde adgang til den lukkede grevestol (til venstre $i$ billedet). Herfra havde greveparret en god udsigt til præsten på prædikestolen - når de fine folk ellers var til stede $i$ kirken. Umiddelbart foran prædikestolen, men på kirkens gulv, ses de tidligere herskabsstole. Her sad godsets inspektor, betjente og ovrige personale efter 1692, mens deres hustruer havde de tilsvarende pladser $i$ kirkens nordside (under grevestolen). De bedste pladser var altså reserveret Schackenborgs ejere og deres nærmeste ansatte. Af billedet fornemmer man, hvorfor stolene $i$ koret blev anset for de ringeste. Herfra var udsigten til prædikestolen og pulpiturerne dårlig. Det har kun hjulpet lidt, at bondekonerne $i$ koret bedre kunne folge med, når der var barnedäb $i$ kirken, og at de desuden sparede lidt penge $i$ forhold til folkene på de dyrere pladser $i$ kirkens skib. Pladserne var og blev de ringeste, og sad man her, var det tegn på ens lave status - eller $i$ det mindste ens dårlige okonomi. Foto: Nationalmuseet.

Patronernes indflydelse har overvejende været indirekte når bortses fra pulpituret og begravelsen. Lensgreven skulle i princippet godkende alle større byggearbejder og nyanskaffelser, hvis ikke han ligefrem tog initiativet. I praksis var det dog grevskabets inspektør, der tog sig af de daglige forretninger. Formodentlig har han kun forelagt de vigtigste sager for greven. Anskaffelsen af kirkens orgel kan tjene som et eksempel på den forholdsvis selvstændige stilling, inspektøren indtog på vegne af herskabet overfor kirken. ${ }^{49}$

Orgelsagen var et resultat af den uro, der herskede i forholdet mel- 
lem herskab og bønder $i$ den første greves tid. Ved overtagelsen af Møgeltønderhus i 1661 havde dette været i en sørgelig forfatning. Hans Schack udskød derfor at etablere hovedgårdsdriften, indtil godset var genopbygget og organiseret påny. Forholdet til de hoveripligtige fæstebønder blev ordnet midlertidigt med en skriftlig overenskomst. Schacks arbejde med at gøre godset rentabelt førte imidlertid til flere krænkelser af overenskomsten, og også på andre måder følte bønderne sig dårligt behandlet. I 1672 sluttede Møgeltønder birks bønder sig derfor sammen og bad birkeskriveren Anders Nissen føre deres sag. Den dramatiske sag skal ikke gentages her, blot skal en enkelt begivenhed nævnes: I 1674 fik Schack Anders Nissen og dennes broder Karsten dømt til døden. På grevens befaling fik de dog dommen eftergivet, men for Anders Nissens vedkommende skete dette forst på selve retterstedet. Istedet pålagdes han at betale 200 rigsdaler til et nyt orgel til kirken. Bag bødestraffen stod godsets inspektør Nikolaus Tych, og i denne sag ser han ud til at have handlet mod grevens vilje. Denne mente at Anders Nissen slap for billigt, hvilket dog formodentlig forblev mellem godsejeren og inspektøren. Godsejerens del af bøden (sagefaldet) ville under normale omstændigheder være tilfaldet Hans Schack, men nu kom det istedet til at gå til kirkens nye orgel.

Herskabspulpitur og stolestadeordning, gravkrypt- og kapel samt orgel var store og meget synlige dele af inventaret. Men patronerne satte også deres aftryk andre steder i kirken. Til skiftende tider gav de kirken inventar med navnetræk og våben, og af det der fortsat eksisterer (eller som vi har kendskab til), kan bl.a. nævnes et alterklæde (nævnt 1766), en oblatæske (1750) og en vinkande (1674). Også korgitteret fra 1653 blev på et tidspunkt før 1766 forsynet med det grevelige våben og navne.

Schackenborgs interesse for sognekirken Møgeltønder var markant større end interessen for de øvrige patronatskirker. Alligevel fandtes der i de enkelte kirker inventar, givet af Schack'erne og med navnetræk og våben. ${ }^{50}$ Mest iøjnefaldende var vel alterklæderne i Ballum og Daler, begge formodentlig skænket at Otto Didrik Schack (lensgreve 1719, død 1741). Derudover fandtes der i Ballum en kirkeklokke (1709) med det Schackske våben, i Emmerlev en sygekalk og disk (1745) med Anna Ernestine Schacks navn og i Daler henholdsvis en messehagel skænket af grev Schack i 1670'erne og en disk (1751) med Schacks våben. Selvom f.eks. messeklæder, alterduge og altersølv 
med forbindelse til Schackenborg sagtens kan være gået til, så var patronerne næppe særlig synlige i disse kirker, kun i Møgeltønder var deres fremtræden påfaldende. Ligesom Trøjborgs ejere var Schackerne mest optaget af deres egen sognekirke.

\section{Afrunding}

Schackenborg og Trøjborg var på mange måder to vidt forskellige godser, men i forholdet til de underliggende patronatskirker var der alligevel mange fælles træk. Først og fremmest havde ingen af godserne nogen væsentlig okonomisk fordel af patronatsretten $i$ form af naturalie- eller pengeindtægter, på det tidspunkt hvor rettighederne blev erhvervet eller i tiden umiddelbart derefter. Motivet for erhvervelsen kan derfor ikke antages at have været økonomisk. Dog indgik kirkerne med gods og tiender i Schackenborggrevskabets samlede hartkorn, der derved kom nærmere de 2.500 td, som var betingelsen for oprettelsen af et grevskab.

Ejerne af begge godser ses derimod på hver deres måde at have benyttet godsets sognekirker til en meget markant fremhævelse af sig selv - til selviscenesættelse. Der kan næppe herske tvivl om, at kirkernes væsentligste funktion var at bidrage til patronernes markering af deres sociale status - et forhold af stor betydning i det standsorienterede samfund fra 15-1700-tallet. Kirkerne har ikke spillet nogen afgørende rolle; slægt, embeder, rigdom og godsbesiddelse var trods alt det vigtigste. Men patronatsretten var ligesom godsernes nye hovedbygninger, luksusforbruget, rejserne, titlerne m.v. med til at skabe indtrykket af godsejeren som en mægtig og magtfuld mand. 


\section{NOTER}

1. Jus patronatus var betegnelsen for overhøjheden over kirkelige institutioner. Patronatsretten indeholdt som regel retten til at besætte gejstlige embeder og forpligtigelsen til at varetage institutionens forsvar. Derudover kunne indholdet variere, og patroner og kirkeledelse ses ofte at have været uenige om rettighedernes omfang. Jvf. Artikel "patronatsret« i: Dansk kulturhistorisk opslagsværk, Kbh. 1991.

2. Jesper Thomassen: Kronens afhændelser af dens fynske jus patronatus 1646-1698, i: Historie 1994.

3. Kansler Johan Friis' erhvervelse af jus patronatus til Hagested kirke 1541 regnes almindeligvis som det første eksempel, Kanc. brevb. 16. sept. 1541. Jvf. dog Anders Jahansens overtagelse af patronatsretten til Graverslund kirke efter Stie Pors, Kanc. brevb. 15. marts 1538.

4. Ejvind Slotved: Studier over kongetienden efter 1536, i: Festskrift til Svend Ellehøj, Kbh. 1984. Jesper Thomassen: Sognepræsten som Statstjener 15361660 , utrykt ph.d.-afhandling, Odense 1996.

5. Jesper Thomassen: Kronens afhændelser af dens fynske jus patronatus 1646-1698, i: Historie 1994.

6. Jvf. kort i Gyldendals Danmarkshistorie, bd. 2.2.

7. En del kirker i de fællesregerede områder kom dog under adelig jus patronatus; nemlig Gram og Fole (Hans Schack, Gram slot 1673), Kliplev, Kværs og Asbøl (Ahlefeldterne på Søgård), Dybbøl (Reventlow, grevskabet Reventlow 1676). Se Danmarks Kirker.

8. Kronens skøder 17. okt. 1579.

9. LAa, Af Ribe bispearkiv, nr. 160 (ad reg. nr. 7. Capsa 18. pk. 11, Trøjborg 1579-80. Genparter).

10. Ibid.

11. V. A. Secher: Samling af Kongens Rettertings Domme 1595-1604, Kbh. 1881-83, 21. juni 1598. Jvf. P. Feddersen Jensen: Visby sognekrønike, Visby 1946.

12. Kronens skøder 1. nov. 1661 og 4. nov. 1673.
13. Kronens skeder 3. jan. 1683.

14. J. P. Trap: Hertugdømmet Slesvig 1864.

15. Jvf. Jesper Thomassen: Kronens afhændelser af dens fynske jus patronatus 1646-1698, i: Historie 1994.

16. Jvf. C. T. Engelstoft: Om beskikkelse af kirkens tjenere $i$ den danske kirke fra reformationen til vore tider. Patronatsretten, i: Theologisk Tidsskrift 1842. P. Severinsen: Folkekirkens ejendomshistorie, Kbh. 1920.

17. En oversigt over præsteindberetningerne gives af Gunnar Olsen: Indberetninger om sognekaldenes og kirkernes økonomiske vilkår, i: Fortid og Nutid 1956. Jvf. Jesper Thomassen: Sognepræsten som statstjener 15361660, Odense 1996.

18. F.eks. Holger F. Rordam: Om godsejernes udøvelse af patronatsretten 1670-91, i: Kirkehistoriske Samlinger 1867-48. Jvf. sagen om Peter Rantzaus ombygning af Visby kirke.

19. F.eks. reces 1643 I. 4.2. Udgivet af V. A. Secher: Forordninger og recesser, bd. 5, Kbh. 1903.

20. LAa, diverse vestslesvigske kirkeregnskabsbøger ca. 16-1700. Jvf. Georg Rasmussen (udg.): Ullerup kirkeregnskabsbog 1606-1650, 1997.

21. LAa, Schackenborg godsarkiv, pk. 5.

22. LAa, Schackenborg og Trøjborg godsarkiver, diverse jordebøger og matrikler.

23. LAa, Schackenborg godsarkiv, pk. 541. Jordebog august 1663.

24. Kronens skader 3. jan. 1683.

25. LAa, Schackenborg godsarkiv, især pk. 499, 515, 523 og 534 .

26. Danske kancelliregistranter 6 . januar 1547. Jvf. sst. 3. december 1546. Det angives her, at Iver Eriksens (Rosenkrantz) forældre var giverne, hvilket dog muligvis skal forstås som hans forfædre.

27. LAa, Emmerlev præstearkiv, Cb1, En rigtig fortegnelse, paa Emmerlev præstis oc kierckens tieneres jordegods, 1690. Jvf. Gunnar Olsen: Indberetninger om sognekaldenes og kirkernes økonomiske vilkår, i: Fortid og Nutid 1956. 
28. Claus Clausen nævner selv i sin indberetning ærkedegnen B. Erasmi Heidtmands brev om sagen dateret Sejerslev d. 24. april 1598, så opgivelsen af kapellaniet er formodentlig sket omkring dette tidspunkt. Claus Clausen havde i 1690 en personlig kapellan, men det kan have været som følge af hans alders skrøbelighed.

29. Peter Kr. Iversen: Herremand og bonde i Vestslesvig i 1660'erne og 1670'erne, i: Sønderjyske Årbøger 1942.

30. LAa, Schackenborg godsarkiv, bla. pk. 473, diverse jordebøger og matrikler.

31. LAa, Af Ribe bispearkiv, nr. 160. Læg med titlen: Trøjborg 1579-80.

32. LAa, Trøjborg godsarkiv, pk. 47, Sager vedr. kirker og skoler 1583-1835. I et åbent brev dateret 8. febr. 1583 meddeler Peder Rantzau, at han har modtaget klagen, og at denne skal bringes for Lø herredsting.

33. LAa, jordebøger i Trøjborg godsarkiv samt kirkeregnskaber i Ribe bispearkiv, nr. 213-216.

34. Danmarks kirker.

35. LAa, Trøjborg godsarkiv, pk. 68, Forskelligt 1586-1828.

36. LAa, Trøjborg godsarkiv, pk. 47, Sager vedr. kirker og skoler 1583-1835. Aftalen er underskrevet af begge parter og dateret 2. febr. 1591.

37. V. A. Secher: Forordninger og recesser, bd. 5, Kbh. 1903, s. 192.

38. LAa Ribe bispearkiv, nr. 175. Jvf. Gunnar Olsen: Præsteindberetninger om sognekaldenes og kirkernes økonomiske vilkår, i: Fortid og Nutid 1956. Thade Petersen: Præstekaar og Kirke- eje i vestslesvigske sogne i 16 og 17 . Aarhundrede, i: Sønderjyske Årbøger 1930.

39. LAa, Brede præstearkiv, Bd 3, Sager vedr. kirke- og præstegårdsjord 16861936.

40. Se Axel Bolvig: Kirkekunstens storhedstid, Kbh. 1992. Samme: Bondens billeder, Kbh. 1994.

41. Se Axel Bolvig: Reformationens rindalister, Kbh. 1996.

42. Danmarks Kirker, Tønder Amt, Brede sogn. Jvf. Johan Hvidtfeldt: Bidrag til belysning af de kirkelige forhold i Vestslesvig omkring 1650, i: Sønderjyske Årbøger 1941.

43. LAa, Trøjborg godsarkiv, diverse jordebøger.

44. H. Knudsen: Visby Kirkes Spir, i Samlinger til jysk historie og topographi, 4. rk. 4.

45. Danmarks Adels Aarbog 1930, stamtavle s. 26.

46. Danmarks kirker. LAa, Schackenborg godsarkiv, pk. 499, kirkeregnskabsbog.

47. LAa, Schackenborg godsarkiv, pk. 503 , i aflang bog og dateret 23. maj 1692. Den oprindelige tekst er dansk, men med en del senere tilføjelser og rettelser på tysk.

48. Personerne på pulpituret er så vidt muligt identificeret ved hjælp af matriklerne fra $1680^{\prime}$ erne og $90^{\prime}$ erne samt et skatteregister fra 1719. LAa, Schackenborg godsarkiv pk. 573 og 800.

49. Jvf. Peter Kr. Iversen: Herremand og bonde i Vestslesvig i 1660'erne og 1670'erne, i: Sønderjyske Aarbøger 1942.

50. Danmarks Kirker, Tønder amt. 